\title{
Influence of Geographic Origin and Plant Source on Physicochemical Properties, Mineral Content, and Antioxidant and Antibacterial Activities of Moroccan Propolis
}

\author{
Naoual El Menyiy $\mathbb{D}^{D}$, Meryem Bakour $(\mathbb{D}$, Asmae El Ghouizi $(\mathbb{D}$, Soukaina El Guendouz $(\mathbb{D}$, \\ and Badiaa Lyoussi $\mathbb{C}$
}

Laboratory of Natural Substances, Pharmacology, Environment, Modeling, Health, and Quality of Life (SNAMOPEQ), Faculty of Sciences Dhar Mehraz, Sidi Mohamed Ben Abdellah University, Fez, Morocco

Correspondence should be addressed to Badiaa Lyoussi; lyoussi@gmail.com

Received 24 January 2021; Revised 3 March 2021; Accepted 8 March 2021; Published 19 March 2021

Academic Editor: Severino Matias de Alencar

Copyright (c) 2021 Naoual El Menyiy et al. This is an open access article distributed under the Creative Commons Attribution License, which permits unrestricted use, distribution, and reproduction in any medium, provided the original work is properly cited.

\begin{abstract}
This research is aimed at determining the physicochemical properties (resin, wax, balsams, pH, moisture, ash, and mineral contents) of propolis samples collected from different geographical areas in Morocco, as well as evaluating the antioxidant and antibacterial activities of these samples. The results showed the following values for physicochemical analysis: resin (17.42$58.01 \%)$, wax (21.31-70.12\%), balsam (0.27-2.12\%), pH (3.7-5.3), moisture (1.02-3.65\%), and ash (0.72-5.01\%). The phenolic and flavone/flavonol contents of samples were ranged between $6.74 \mathrm{mg} \mathrm{FAE} / \mathrm{g}$ and $149.13 \mathrm{mg} \mathrm{FAE} / \mathrm{g}$ and between $1.19 \mathrm{mg} \mathrm{QE} / \mathrm{g}$ and $108.11 \mathrm{mg}$ QE/g, respectively. The sample P3 presented also the strongest radical scavenging activity toward DPPH, ABTS free radicals, and FRAP assay with $\mathrm{IC}_{50}$ values of $0.021,0.026$, and $0.042 \mathrm{mg} / \mathrm{mL}$, respectively. All propolis samples showed significant inhibitory effects against all tested microorganisms with MICs ranging from $0.28 \mathrm{mg} / \mathrm{mL}$ to $1.12 \mathrm{mg} / \mathrm{mL}$ for Gramnegative strains and from $0.002 \mathrm{mg} / \mathrm{mL}$ to $1.12 \mathrm{mg} / \mathrm{mL}$ for Gram-positive strains. A strong correlation was found between resin, total phenolic compounds, flavones/flavonols, and antioxidant activity. Linear discriminant analysis revealed that the samples studied were divided into two groups which were differentiated by the data of antioxidant activity, mineral contents, and antibacterial activity. It can be concluded that the physicochemical properties, mineral content, and biological activities of Moroccan propolis depend on their geographical and botanical origin.
\end{abstract}

\section{Introduction}

Propolis or "bee glue" is a resinous substance collected by honeybees (Apis mellifera L.) from the resin found on the buds of trees and plants [1]. This material is transported to the hive and mixed with 13-glycosidase enzymes of their saliva, partially digested, and added to bee wax and pollen producing a strongly adhesive substance, which is used by bees for the construction and maintenance of hives $[2,3]$. In general, this bee product contains $50 \%$ resins, $30 \%$ waxes, $10 \%$ essential oils, $5 \%$ pollen, and $5 \%$ other organic compounds, including the phenolic compounds, amino acids, esters, flavonoids, and terpenes [4].
Propolis is used for therapeutic purposes since ancient times [5]. Nowadays, several studies shed light on the biological activities of propolis, such as antimicrobial $[6,7]$, antiinflammatory [8], antiviral [9], hepatoprotective [10], immunomodulatory [11], antioxidant [12, 13], and anticancer activities [14].

A considerable amount of literature has been published on the biological activities of Moroccan propolis. El Menyiy et al. reported that Moroccan propolis has a potential to prevent urinary against calculus, crystalluria, and proteinuria [15]. Similarly, other studies showed that Moroccan propolis has a protective effect against renal, hepatic, and hematological toxicity caused by paracetamol and chromium $[16,17]$. 
Recently, in vivo studies have shown that Moroccan propolis exhibited a promising antidiabetic activity; it significantly decreased blood glucose level, increased insulin sensitivity and pancreatic $\beta$ cell function, ameliorated dyslipidemia by the decrease of TC, TG, LDL-C, and VLDL and the increase of HDL, and prevented diabetic complications such as liver and kidney injury $[18,19]$. Other reports showed that Moroccan propolis has a strong antioxidant, antibacterial, anti-inflammatory, and anticancer potential [20-24]. Importantly, the chemical composition of Moroccan propolis revealed the presence of caffeic acid, pcoumaric acid, ferulic acid, naringenin, pinocembrin, chrysin, galangin, pinobanksin, and quercetin, which are known for their broad spectrum of biological activity [11, 21].

The biological effects and chemical composition of propolis vary according to many factors such as geographical origin, botanical source, honey bee species, climate environmental conditions, and collecting season $[25,26]$. Therefore, the main objective of the present work was to investigate the physicochemical parameters and antioxidant and antibacterial activities of twenty propolis samples collected from different botanical sources and geographical origins in Morocco.

\section{Materials and Methods}

2.1. Propolis Extraction. Twenty samples of propolis were collected from different regions of Morocco by professional beekeepers. The cities of sampling and the predominant vegetation in each city are presented in Table 1 . The samples were extracted by maceration using the method described by El-Guendouz et al. [23] with some modifications. One gram of each propolis sample was macerated in $10 \mathrm{~mL}$ of $70 \%$ ethanol for 7 days at room temperature under physical agitation. The final extract was filtered and centrifuged at 4,000 rpm for 10 minutes, and the supernatant was used for successive analyses.

\subsection{Physicochemical Characterization of Propolis Samples}

2.2.1. $\mathrm{pH}$. The $\mathrm{pH}$ meter was used to determine the $\mathrm{pH}$ value of propolis solution that was prepared by dissolving five grams of each propolis sample in $30 \mathrm{~mL}$ of methanol [27].

2.2.2. Ash Content. For the determination of the ash content, one gram of each sample was placed in a crucible in a muffle furnace and heated at $550^{\circ} \mathrm{C}$ for five hours. The results were expressed as percentage $w / w[28]$.

2.2.3. Moisture Content. The AOAC method was used to determine the moisture content of propolis samples [29]. Briefly, one gram of propolis sample was placed in a crucible in a furnace and heated at $105^{\circ} \mathrm{C}$ to a constant weight.

2.2.4. Wax, Resin, and Balsam Contents. The content of wax, resin, and balsam in different propolis samples was estimated according to the methods described by Papotti et al. [30], with slight modification. Briefly, one gram of propolis was macerated with $40 \mathrm{~mL}$ of petroleum ether at $40-60^{\circ} \mathrm{C}$ under stirring for $48 \mathrm{~h}$. The extract was added to $40 \mathrm{~mL}$ of $70 \%$ eth- anol, heated under reflux until a clear solution was obtained, and then cooled at $0^{\circ} \mathrm{C}$ for $1 \mathrm{~h}$ to promote wax separation. The results were expressed as a percentage $(w / w)$, representing the rate of wax in each propolis sample. Concerning the resin content, the residual propolis obtained after the wax extraction was macerated with $40 \mathrm{~mL}$ of chloroform and ethanol $1: 1(v / v)$ under stirring for $48 \mathrm{~h}$. The extract was concentrated in a rotary evaporator to obtain a solid residue; the results were expressed as $\% w / w$. The balsam content was estimated as follows: the $70 \%$ ethanolic filtrate obtained during the wax extraction was concentrated under reduced pressure at $60^{\circ} \mathrm{C}$. Then, $10 \mathrm{~mL}$ of dichloromethane was added to the aqueous residue; the organic phase was collected and dried over $6 \mathrm{~g}$ of anhydrous $\mathrm{Na}_{2} \mathrm{SO}_{4}$ and then filtered. The solution was evaporated to dryness under reduced pressure at $60^{\circ} \mathrm{C}$. The results were expressed as a percentage $(w / w)$, representing the rate of balsam in each propolis sample.

2.3. Mineral Content. The mineral content of propolis samples was determined by Inductively Coupled Plasma Mass Spectrometry (ICP-MS) following the procedure described by Silva et al. [31]. Briefly, $5 \mathrm{~mL}$ of $0.1 \mathrm{M}$ nitric acid was added to the ashes and heated to complete dryness. Then, $10 \mathrm{~mL}$ of $0.1 \mathrm{M}$ nitric acid was added, and the volume was made up to $25 \mathrm{~mL}$ with distilled water. The values were calculated as $\mathrm{mg}$ of each mineral element per $\mathrm{kg}$ of propolis.

\subsection{Antioxidant Properties of Propolis Samples}

2.4.1. Total Phenolic Content. Folin-Ciocalteu's method was used to determine the polyphenol content in propolis samples according to the procedure described by El-Guendouz et al. [23]. The resulting values were expressed as mg ferulic acid equivalents per $\mathrm{g}$ of propolis (mg FAE/g).

2.4.2. Flavone and Flavonol Content. The aluminium chloride was used to determine the flavone and flavonol content in propolis samples according to the method described by ElGuendouz et al. [23]. The resulting values were expressed as $\mathrm{mg}$ quercetin equivalents per $\mathrm{g}$ of propolis $(\mathrm{mg} \mathrm{QE} / \mathrm{g})$.

\subsection{Antioxidant Activity}

2.5.1. Total Antioxidant Capacity. The phosphomolybdenum method was used to evaluate the total antioxidant capacity of the propolis extract as described by Zengin et al. [32]. The resulting values were expressed as milligram equivalents ascorbic acid per gram of propolis (mg AAE/g propolis).

2.5.2. Free-Radical Scavenging Activity ( $D P P H)$. The ability of propolis extract to scavenge the radical 2,2-diphenyl-1picrylhydrazyl (DPPH) was evaluated using the method of Miguel et al. [33]. The absorbance was recorded at $517 \mathrm{~nm}$, the values of $\mathrm{IC}_{50}$ were determined, and $\mathrm{BHT}$ was used as positive control.

2.5.3. Scavenging Activity of ABTS Radical Cation. The ability of propolis extract to scavenge ABTS radical was monitored using the procedure of Miguel et al. [33]. The absorbance was read at $734 \mathrm{~nm}$, and the values of $\mathrm{IC}_{50}$ were determined. Gallic acid was used as positive control. 
TABLE 1: Predominant vegetation in the geographical locations of the propolis samples.

\begin{tabular}{|c|c|c|}
\hline Propolis & City & Predominant vegetation \\
\hline P1 & Séfrou & Bupleurum, Ceratonia, and Eucalyptus \\
\hline $\mathrm{P} 2$ & Moulay Yaâcoub & Ceratonia, Citrus, Eucalyptus, and Silybum \\
\hline P3 & Outat el Haj & Populus, Ceratonia, Eucalyptus, Rosmarinus, and Quercus \\
\hline $\mathrm{P} 4$ & Taza & Ceratonia, Silybum, Thymus, Juniperus, and Rosmarinus \\
\hline P5 & Khénifra & Eucalyptus, Lavandula, and Silybum \\
\hline P6 & Beni Mellal & Ceratonia \\
\hline P7 & Salé & Eucalyptus, Euphorbia, Juniperus, and Quercus \\
\hline P8 & Témara & Eucalyptus, Quercus, Silybum, Rosmarinus, and Thymus \\
\hline P9 & Rabat & Ceratonia, Cistus, Eucalyptus, Thymus, and Quercus \\
\hline $\mathrm{P} 10$ & Tiflet & Ceratonia, Eucalyptus, Thymus, Silybum, and Lavandula \\
\hline P11 & Sidi Kacem & Citrus, Euphorbia, Silybum, Juniperus, and Rosmarinus \\
\hline $\mathrm{P} 12$ & Khnichet & Citrus, Thymus, Lavandula, and Eucalyptus \\
\hline $\mathrm{P} 13$ & Moulay Bousselham & Vaccinium \\
\hline $\mathrm{P} 14$ & Jerada & Citrus, Euphorbia, Thymus, and Lavandula \\
\hline P15 & Oujda & Citrus, Rosmarinus, Silybum, and Juniperus \\
\hline P16 & Ben Slimane & Eucalyptus and Quercus \\
\hline $\mathrm{P} 17$ & Oualidia & Eucalyptus \\
\hline P18 & Errachidia & Euphorbia, Eucalyptus, and Juniperus \\
\hline P19 & Sidi Ifni & Argania and Euphorbia \\
\hline $\mathrm{P} 20$ & Tan-Tan & Euphorbia \\
\hline
\end{tabular}

2.5.4. Reducing Power Determination. The reductive potential of propolis extract was evaluated following the procedure of Moreira et al. [34]. The absorbance was recorded at $700 \mathrm{~nm}$, and $\mathrm{IC}_{50}$ was determined. The test has been done in triplicate, and ascorbic acid was used as positive control.

\subsection{Antibacterial Activity of Propolis Samples}

2.6.1. Bacterial Strains. The antibacterial activity of propolis extracts was evaluated against four bacterial strains: two Gram-negative strains (Escherichia coli BLSE (ATB:87) and Pseudomonas aeruginosa) and two Gram-positive strains (Streptococcus faecalis and Staphylococcus aureus); bacterial strains were obtained from the Hassan II University Hospital and Laboratory of Microbiology, Faculty of Medicine and Pharmacy Fez.

2.6.2. Disk Diffusion Method. The disk diffusion method was used to evaluate the antibacterial activity of hydroethanolic extract of propolis [35]. About $20 \mathrm{~mL}$ of Mueller-Hinton agar (MHA) medium was poured into Petri plates. Each Petri plate was inoculated with a bacterial inoculum consisting of $0.5 \mathrm{McF}$ arland $(1-2) * 10^{8} \mathrm{CFU} / \mathrm{mL}$ which was prepared in a physiologic saline buffer. Then, sterile Whatman paper disks were placed on a medium and impregnated with $10 \mu \mathrm{L}$ of hydroethanolic extracts of propolis $(100 \mathrm{mg} / \mathrm{mL})$. Ethanol 70\% was used as a negative control, to check the possible activity of the solvent of extraction against the tested bacterial strains. After $24 \mathrm{~h}$ incubation at $37^{\circ} \mathrm{C}$, the inhibition zone was measured in $\mathrm{mm}$. Each experiment was carried out in triplicate.
2.6.3. Minimum Inhibitory Concentration (MIC). The MIC of each extract was determined following the NCCLS method [36]. It was performed by a serial dilution of propolis extracts which was made in a concentration ranged between 0.048 and $100 \mathrm{mg} / \mathrm{mL} .10 \mu \mathrm{L}$ of each concentration was mixed in a 96-well plate with $180 \mu \mathrm{L}$ of $\mathrm{MH}$ broth and $10 \mu \mathrm{L}$ of bacterial inoculums $\left(5 \times 10^{5} \mathrm{CFU} / \mathrm{mL}\right)$. The concentration of ethanol in each well does not exceed $3.5 \%$ and was used as a negative control. After $20 \mathrm{~h}$ incubation of the microplates at $37^{\circ} \mathrm{C}, 20 \mu \mathrm{L}$ of 2,3,5-triphenyl tetrazolium chloride (TTC) was added to each well and incubated for $30 \mathrm{~min}$. MIC corresponds to the lowest concentration of the extract that inhibited visible growth (indicated by the absence of red colour after the adding of TTC) [37].

2.6.4. Minimal Bactericidal Concentration (MBC). In MullerHinton agar (MHA), each well which the concentration is $\geq \mathrm{MIC}$ was subcultured and incubated at $37^{\circ} \mathrm{C}$ for $24 \mathrm{~h}$. $\mathrm{MBC}$ corresponds to the lowest concentration of the extracts that killed 99.9\% from the inoculated bacteria. The antibacterial effect was considered bactericidal if $\mathrm{MBC} / \mathrm{MIC}=1-2$ and bacteriostatic if $\mathrm{MBC} / \mathrm{MIC}=4$ to 16 [38].

2.7. Statistical Analysis. One-way ANOVA followed by post hoc Tukey's multiple comparison test using GraphPad Prism 5 software was used for statistical comparisons. Pearson correlation coefficient $(r)$ was used to analyze the correlations between different parameters of propolis samples. The results were also subjected to linear discriminant analysis (LDA) using program PAST: paleontological statistics software package for education and data analysis, version 3.20. 


\section{Results and Discussion}

3.1. Physicochemical Characterization. The resin and wax are the main compounds in propolis with a rate of $50 \%$ and $30 \%$, respectively [39]. In the present work, all the physicochemical results of twenty propolis samples are summarized in Table 2; the analysis of the results indicates that the samples have varying amounts of resin, wax, and balsam with significant differences between them. Propolis samples with high wax content had low resin content. As indicated in Table 2, the high wax content is presented in sample P20 and the lowest content in sample P3. For the balsams, sample P6 showed the high content, while the lowest content was obtained in sample P12. The other samples have intermediate balsam content ranged between $0.29 \pm 0.01 \%$ and $1.89 \pm 0.01 \%$. Concerning the resin contents, sample P3 shows the highest value, followed by sample P7. The highest content in the wax, balsam, and resin found in Moroccan propolis samples in this study is in agreement with the range of those generally detected in Italian propolis samples in which resin content ranged between 39.1 and $72.7 \%$ while wax content ranged between 12.8 and $41.0 \%$ [40]. Determination of ash content is an indication that can identify a possible adulteration in propolis samples [41]. The ash content values of all investigated samples ranged from $0.72 \pm 0.02 \%$ to $5.01 \pm 0.01 \%$. All samples agree with the limit established by the Brazilian legislation [42]. Moreover, moisture is also an indication of the quality of propolis; the high water content in propolis indicates inadequate storage and manipulation conditions [43]. The results obtained showed also that moisture content in all analyzed samples does not exceed $3.65 \pm 0.01 \%$; this value is within the limit established by the Brazilian legislation (not more than $8 \%$ ) [42]. The $\mathrm{pH}$ results of the samples were all somewhat acidic ranging between $3.7 \pm 0.2$ in sample $\mathrm{P} 20$ to $5.3 \pm 0.12$ in samples P3, P7, and P16. The $\mathrm{pH}$ values of all investigated samples are in agreement with those obtained in other studies $[27,44,45]$.

3.2. Mineral Content. Table 3 shows the results obtained for the mineral content of twenty Moroccan propolis samples. The concentration of all macro- and microelements was widely varied; the calcium content was the most dominant minerals in all investigated samples and ranged between $210 \pm 31.1 \mathrm{mg} / \mathrm{kg}$ in sample P20 and $1325 \pm 16.1 \mathrm{mg} / \mathrm{kg}$ in sample P3. The sodium content was the second dominant minerals ranged between $51 \pm 10.16 \mathrm{mg} / \mathrm{kg}$ and $690 \pm 13.11$ $\mathrm{mg} / \mathrm{kg}$, followed by potassium content ranging between 116 $\pm 21.15 \mathrm{mg} / \mathrm{kg}$ and $705 \pm 25.28 \mathrm{mg} / \mathrm{kg}$, followed by magnesium content which varies from a minimum value of $58 \pm$ $21.1 \mathrm{mg} / \mathrm{kg}$ to a maximum of $950 \pm 11.17 \mathrm{mg} / \mathrm{kg}$, while the toxic elements $\mathrm{Cd}, \mathrm{Cr}, \mathrm{Co}$, and $\mathrm{Ni}$ are not detected in all samples. However, the $\mathrm{Pb}$ was detected in samples P13 $(0.027 \pm 0.02 \mathrm{mg} / \mathrm{kg})$ and P20 $(0.02 \pm 0.01 \mathrm{mg} / \mathrm{kg})$.

It has been shown that the variation of the mineral elements in the propolis depends on several factors such as the mineral composition of the source plants, humidity, and soil $\mathrm{pH}$ [43]. Other studies showed that the amount of toxic elements depends on the method of harvesting propolis [46]. The profile in mineral elements differs from one sample to another even for samples from the same region of Morocco; therefore, it can be a parameter determining the geographical and botanical origins of propolis [47]. Similar results were reported previously in other studies $[43,47,48]$.

3.3. Bioactive Compounds and Antioxidant Activity. Propolis is constituted mainly by flavonoids, hydroxybenzoic acids, hydroxycinnamic acids, and stilbenes that contribute to their functional properties, including antioxidant and antimicrobial $[49,50]$. Table 4 shows the quantitative difference for total phenolic, flavones, and flavonols in propolis from the different areas of Morocco. For the total phenolic compounds, the concentrations ranged between $6.74 \pm 1.17 \mathrm{mg}$ FAE/g in sample P20 and $149.13 \pm 2.12 \mathrm{mg} \mathrm{FAE} / \mathrm{g}$ in sample P3. The same observation was made for flavones and flavonols where the highest concentration was found in sample P3 (108.11 $\pm 0.51 \mathrm{mg} Q \mathrm{QE} / \mathrm{g})$, immediately followed by samples P7 (46.51 $\pm 3.08 \mathrm{mg} \mathrm{QE} / \mathrm{g})$ and P2 (40.90 $\pm 1.42 \mathrm{mg}$ $\mathrm{QE} / \mathrm{g})$. The concentrations of total phenolic compounds, flavones, and flavonols found in our propolis samples were within the range obtained in Portuguese, Algerian, and Chinese propolis [51-53].

On the other hand, it is well known that propolis exhibits a strong antioxidant activity $[2,54]$. The results of the present work showed a considerable antioxidant activity in all propolis where the sample from Outat el Haj presented the high total antioxidant capacity $(80.82 \pm 2.16 \mathrm{mg} \mathrm{AAE} / \mathrm{g})$ and the best antioxidant activity in the three tests DPPH, ABTS, and reducing power assay, with $\mathrm{IC}_{50}$ values of $0.021 \pm 0.001$ $\mathrm{mg} / \mathrm{mL}, 0.026 \pm 0.0007$, and $0.042 \pm 0.001 \mathrm{mg} / \mathrm{mL}$, respectively, while the sample from Tantan presented the lowest activity with $\mathrm{IC}_{50}$ values of $1.308 \pm 0.018,1.529 \pm 0.015$, and $1.512 \pm 0.106 \mathrm{mg} / \mathrm{mL}$ in $\mathrm{DPPH}, \mathrm{ABTS}$, and reducing power assay, respectively. A significant negative correlation between $\mathrm{IC}_{50}$ values and total phenols, resin, flavones, and flavonols $(p<0.01)$ was found (Table 5$)$. It was observed that propolis with high resin, phenolic, flavone, and flavonol contents has the highest antioxidant activity, which means that the antioxidant activity of the propolis sample may be due to their richness in these groups of compounds. This correlation has also been revealed for Moroccan propolis in several studies [20, 21, 33].

In sum, the screening of different Moroccan propolis samples from various regions, regarding their antioxidant activities, revealed a significant difference among them. As mentioned, the observed differences could be related to the compounds exhibiting the antioxidant capacity in each propolis sample, which, in turn, depends on the flora and geographic origin $[55,56]$.

3.4. Antibacterial Activity. The antibacterial activity for propolis is one of the most documented biological properties in the literature $[57,58]$. Table 6 summarizes the results of the antibacterial activity of hydroethanolic extracts of propolis. All propolis samples presented high antibacterial effects, mostly against Gram-positive bacterial strains.

The antibacterial activity of propolis using the disk diffusion method showed an inhibition diameter ranged between $12.3 \pm 1.5$ and $32.2 \pm 1.1 \mathrm{~mm}$ for Staphylococcus aureus 
TABLE 2: Physicochemical characterization of the analyzed propolis samples.

\begin{tabular}{|c|c|c|c|c|c|c|}
\hline Propolis & Wax (\%) & Resin (\%) & Balsam (\%) & Moisture (\%) & Ash (\%) & $\mathrm{pH}$ \\
\hline $\mathrm{P} 1$ & $61.76 \pm 2.09^{c}$ & $29.56 \pm 0.12^{\mathrm{f}}$ & $0.84 \pm 0.01^{j}$ & $1.05 \pm 0.09^{\mathrm{m}}$ & $3.03 \pm 0.03^{\mathrm{e}}$ & $4.7 \pm 0.2^{\mathrm{a}}$ \\
\hline P2 & $29.33 \pm 1.09^{\mathrm{g}}$ & $47.33 \pm 0.13^{\mathrm{c}}$ & $0.67 \pm 0.01^{\mathrm{kl}}$ & $1.79 \pm 0.01^{\mathrm{j}}$ & $4.16 \pm 0.01^{c}$ & $5.2 \pm 0.12^{\mathrm{a}}$ \\
\hline P3 & $21.31 \pm 0.12^{\mathrm{h}}$ & $58.01 \pm 0.09^{\mathrm{a}}$ & $1.09 \pm 0.01^{\mathrm{g}}$ & $1.02 \pm 0.01^{\mathrm{m}}$ & $5.01 \pm 0.01^{\mathrm{a}}$ & $5.3 \pm 0.12^{\mathrm{a}}$ \\
\hline $\mathrm{P} 4$ & $53.64 \pm 2.01^{\mathrm{d}}$ & $27.32 \pm 0.09^{f}$ & $1.31 \pm 0.01^{\mathrm{f}}$ & $2.32 \pm 0.01^{\mathrm{e}}$ & $2.1 \pm 0.01^{\mathrm{h}}$ & $4.2 \pm 0.3^{\mathrm{ab}}$ \\
\hline P5 & $61.34 \pm 3.02^{c}$ & $28.82 \pm 0.01^{\mathrm{f}}$ & $0.97 \pm 0.01^{\mathrm{gh}}$ & $2.03 \pm 0.06^{\mathrm{g}}$ & $1.6 \pm 0.02^{\mathrm{k}}$ & $4.5 \pm 0.21^{\mathrm{ab}}$ \\
\hline P6 & $68.08 \pm 2.1^{\mathrm{b}}$ & $18.06 \pm 0.02^{\mathrm{j}}$ & $2.12 \pm 0.02^{\mathrm{a}}$ & $1.96 \pm 0.02^{\mathrm{h}}$ & $2.15 \pm 0.01^{\mathrm{h}}$ & $4.1 \pm 0.11^{\mathrm{ab}}$ \\
\hline P7 & $23.25 \pm 0.09^{\mathrm{h}}$ & $56.21 \pm 1.02^{\mathrm{b}}$ & $1.78 \pm 0.01^{\mathrm{d}}$ & $1.32 \pm 0.01^{\mathrm{k}}$ & $4.52 \pm 0.01^{\mathrm{b}}$ & $5.3 \pm 0.2^{\mathrm{a}}$ \\
\hline P8 & $32.18 \pm 0.08^{g}$ & $45.7 \pm 0.19^{\mathrm{cd}}$ & $1.89 \pm 0.01^{\mathrm{c}}$ & $1.76 \pm 0.01^{j}$ & $1.09 \pm 0.01^{\mathrm{m}}$ & $5 \pm 0.11^{\mathrm{a}}$ \\
\hline P9 & $52.84 \pm 1.02^{\mathrm{d}}$ & $42.14 \pm 1.09^{\mathrm{e}}$ & $0.65 \pm 0.01^{\mathrm{kl}}$ & $2.87 \pm 0.02^{\mathrm{c}}$ & $3.39 \pm 0.01^{\mathrm{d}}$ & $5.2 \pm 0.2^{\mathrm{a}}$ \\
\hline $\mathrm{P} 10$ & $48.22 \pm 1.92^{\mathrm{e}}$ & $39.3 \pm 0.09^{\mathrm{e}}$ & $1.04 \pm 0.01^{\mathrm{g}}$ & $2.05 \pm 0.02^{\mathrm{g}}$ & $1.49 \pm 0.01^{j}$ & $4.2 \pm 0.21^{\mathrm{ab}}$ \\
\hline $\mathrm{P} 11$ & $47.58 \pm 1.23^{\mathrm{e}}$ & $29.54 \pm 0.08^{\mathrm{f}}$ & $1.67 \pm 0.02^{\mathrm{e}}$ & $2.11 \pm 0.01^{\mathrm{f}}$ & $4.18 \pm 0.08^{\mathrm{c}}$ & $4 \pm 0.22^{\mathrm{abc}}$ \\
\hline $\mathrm{P} 12$ & $26.09 \pm 1.08^{\mathrm{h}}$ & $41.06 \pm 1.08^{\mathrm{e}}$ & $0.27 \pm 0.01^{\circ}$ & $2.14 \pm 0.01^{\mathrm{f}}$ & $2.04 \pm 0.02^{\mathrm{hi}}$ & $5.1 \pm 0.32^{\mathrm{a}}$ \\
\hline $\mathrm{P} 13$ & $46.54 \pm 1.03^{\mathrm{e}}$ & $30.46 \pm 0.09^{\mathrm{f}}$ & $0.86 \pm 0.01^{\mathrm{j}}$ & $2.32 \pm 0.02^{\mathrm{e}}$ & $2.06 \pm 0.01^{\mathrm{h}}$ & $4.8 \pm 0.21^{\mathrm{a}}$ \\
\hline P14 & $30.42 \pm 1.02^{\mathrm{g}}$ & $49.3 \pm 0.18^{\mathrm{c}}$ & $0.56 \pm 0.01^{\mathrm{n}}$ & $2.11 \pm 0.02^{\mathrm{f}}$ & $2.53 \pm 0.01^{\mathrm{g}}$ & $5 \pm 0.22^{\mathrm{a}}$ \\
\hline P15 & $53.23 \pm 1.12^{\mathrm{d}}$ & $22.19 \pm 0.19^{\mathrm{i}}$ & $0.29 \pm 0.01^{\circ}$ & $3.01 \pm 0.01^{\mathrm{b}}$ & $2.89 \pm 0.01^{\mathrm{f}}$ & $4.2 \pm 0.11$ \\
\hline P16 & $37.38 \pm 0.92^{\mathrm{f}}$ & $48.06 \pm 0.14^{\mathrm{c}}$ & $1.98 \pm 0.01^{\mathrm{b}}$ & $1.87 \pm 0.02^{\mathrm{i}}$ & $3.02 \pm 0.02^{\mathrm{e}}$ & $5.3 \pm 0.12^{\mathrm{a}}$ \\
\hline P17 & $37.18 \pm 1.09^{\mathrm{f}}$ & $23.42 \pm 0.12^{\mathrm{i}}$ & $0.76 \pm 0.01^{\mathrm{k}}$ & $1.12 \pm 0.01^{1}$ & $4.13 \pm 0.01^{\mathrm{c}}$ & $4 \pm 0.11^{\mathrm{abc}}$ \\
\hline P18 & $60.50 \pm 2.01^{c}$ & $24.20 \pm 0.09^{\mathrm{i}}$ & $0.96 \pm 0.01^{\mathrm{gh}}$ & $2.45 \pm 0.01^{\mathrm{d}}$ & $1.45 \pm 0.02^{\mathrm{j}}$ & $4.2 \pm 0.21^{\mathrm{ab}}$ \\
\hline P19 & $48.02 \pm 1.02^{\mathrm{e}}$ & $28.08 \pm 0.12^{\mathrm{f}}$ & $0.94 \pm 0.02^{\mathrm{gh}}$ & $2.32 \pm 0.02^{\mathrm{e}}$ & $1.21 \pm 0.01^{1}$ & $4.4 \pm 0.31^{\mathrm{ab}}$ \\
\hline P20 & $70.12 \pm 2.01^{\mathrm{a}}$ & $17.42 \pm 0.09^{j}$ & $0.74 \pm 0.01^{\mathrm{k}}$ & $3.65 \pm 0.01^{\mathrm{a}}$ & $0.72 \pm 0.02^{\mathrm{n}}$ & $3.7 \pm 0.2^{\mathrm{d}}$ \\
\hline
\end{tabular}

Note. Values in the same column followed by the same letter are not significantly different $(p<0.05)$ by Tukey's multiple range test.

followed by Streptococcus faecalis, with a diameter ranged from $10 \pm 0.12$ to $31.5 \pm 1.1 \mathrm{~mm}$, and Escherichia coli with a diameter varied from $8.12 \pm 1.09$ to $19.33 \pm 2.51 \mathrm{~mm}$. The Pseudomonas aeruginosa has the lowest value of the inhibition diameter $(8.02 \pm 0.5$ to $12.3 \pm 0.5 \mathrm{~mm})$. The propolis sample $\mathrm{P} 3$ which has high resin, phenol, flavone, and flavonol contents and higher total antioxidant was the most effective against all bacteria.

Concerning the minimum inhibitory concentrations and the minimum inhibitory concentrations, for all strains, the MIC and MBC values varied between $0.002 \pm 0.0001$ $\mathrm{mg} / \mathrm{mL}$ and $1.12 \pm 0.01 \mathrm{mg} / \mathrm{mL}$, respectively. Among, the bacterial strains tested, Staphylococcus aureus was the most susceptible as compared to other bacteria, while Streptococcus faecalis was the most resistant. These results have also been confirmed by several studies demonstrating the strong antimicrobial activity of propolis extract against bacteria especially Gram-positive strains [59-61]. Propolis sample from Outat el Haj presented the best antibacterial effect with the lowest value of MIC $(0.28 \pm 0.02,0.002 \pm 0.0001,0.56$ \pm 0.01 , and $0.07 \pm 0.001 \mathrm{mg} / \mathrm{mL}$ ) for Escherichia coli, Staphylococcus aureus, Pseudomonas aeruginosa, and Streptococcus faecalis, respectively, followed by the sample from Salé with MIC values of $0.28 \pm 0.02,0.002 \pm 0.0001,0.56 \pm 0.01$, and $0.28 \pm 0.01 \mathrm{mg} / \mathrm{mL}$ for Escherichia coli, Staphylococcus aureus, Pseudomonas aeruginosa, and Streptococcus faecalis, respectively. However, propolis sample from Tantan and ethanol have no effect against all bacteria tested.

The antibacterial effect of propolis could be attributed to its phenolic compounds. It is well known that phenolic acids and flavonoids nullify the potential of the internal bacterial membrane, decrease the production of ATP, and inhibit DNA gyrase involved in the synthesis of bacterial DNA and RNA which leads to the inhibition of bacterial viability [62, 63]. Interestingly, numerous researchers improved the toxic effects of minerals such as iron, phosphorus, cooper, and zinc on both Gram-positive and Gram-negative bacteria [58, 64, 65]; therefore, the richness in macro- and microelements gives propolis an additional potential antibacterial.

The difference observed in the antibacterial activity of the propolis samples could be attributed to the diversity of the bioactive molecules presented in each sample which is related to the botanical and geographical origin of propolis and climatic conditions [66-68].

3.5. Linear Discriminant Analysis (LDA). Figure 1 shows the results of linear discriminant analysis addressing each sample of propolis to one of the following groups: group 1 composed by samples with high wax content (>30\%) [69] and group 2 composed by samples with high content of phenolic compounds using antioxidant activity data, data of minerals present and data of antibacterial activity as dependent variables. The analysis allowed us to obtain just one canonical function that clearly separates the two groups. All propolis samples were correctly classified by LDA $(100 \%)$; these results showed that the two groups of propolis can be differentiated by considering the mentioned variables. Similar results were observed in a study concerning seven Moroccan propolis, which confirmed that samples with high wax content have low phenolic compounds and low antimicrobial activities [21]. 


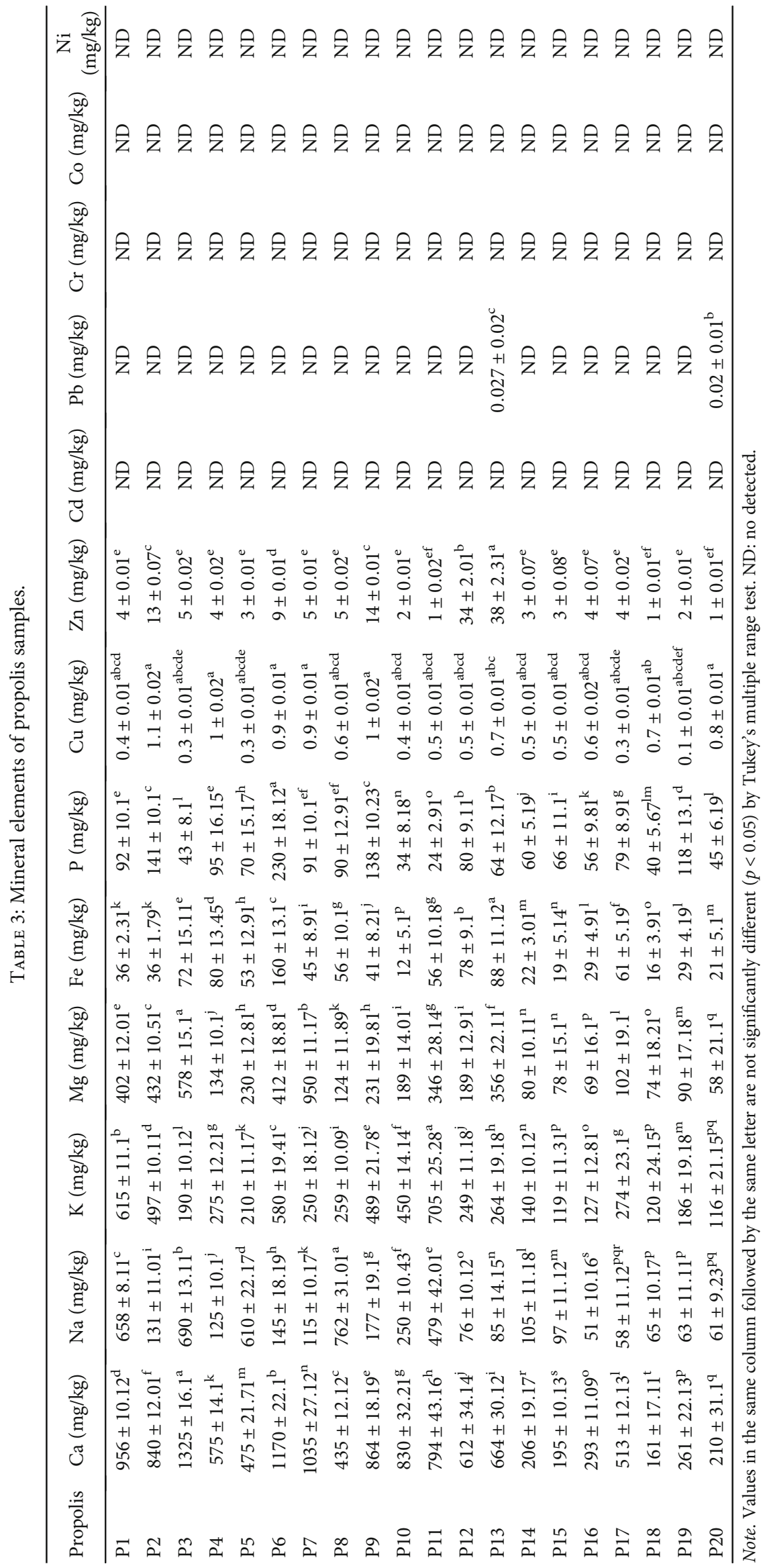




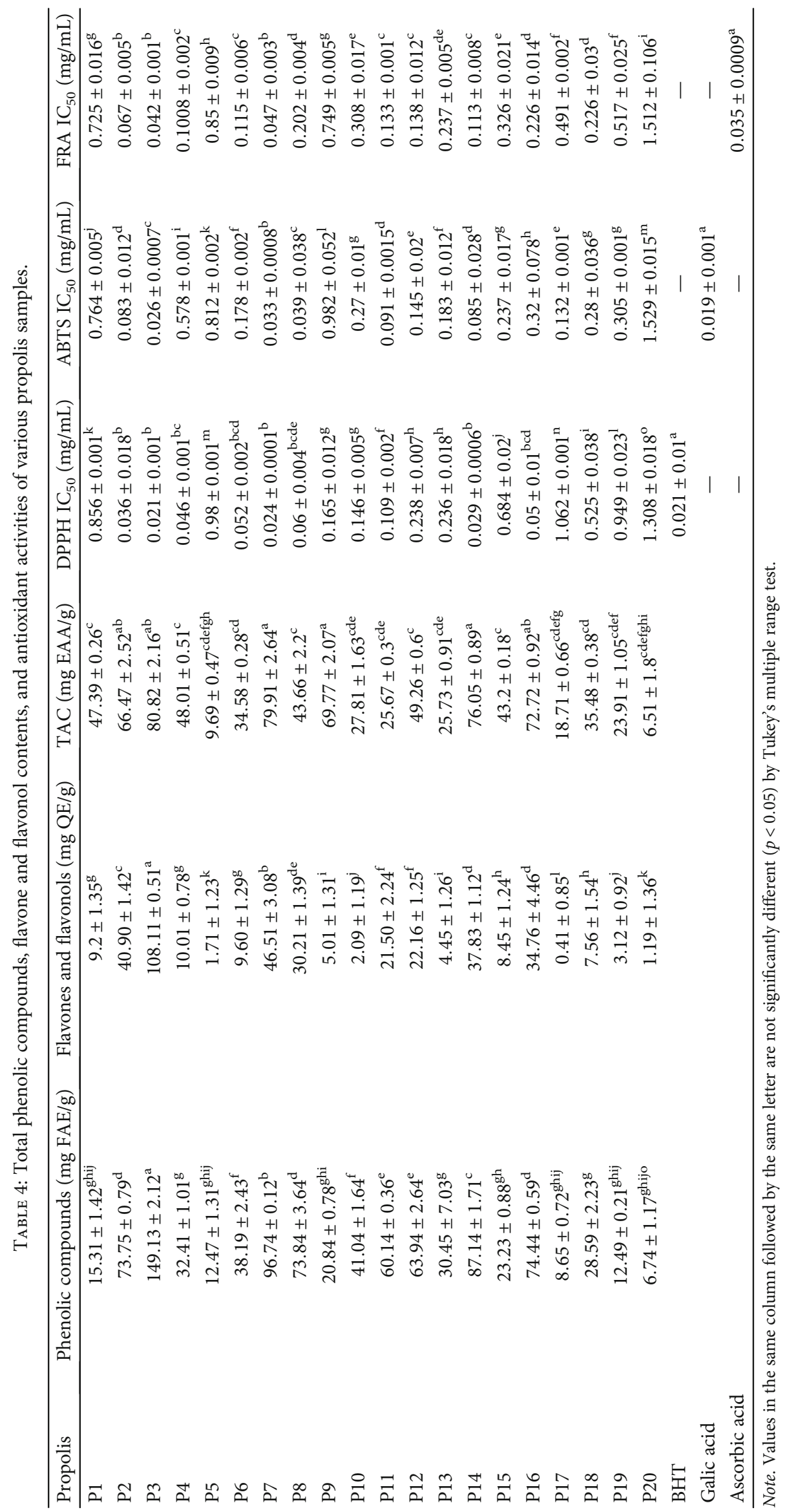




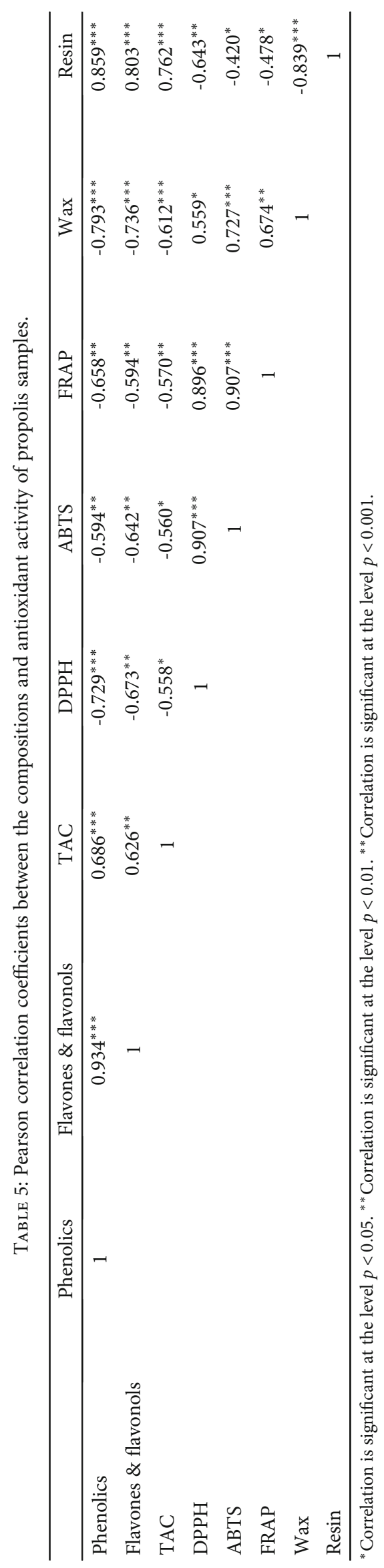




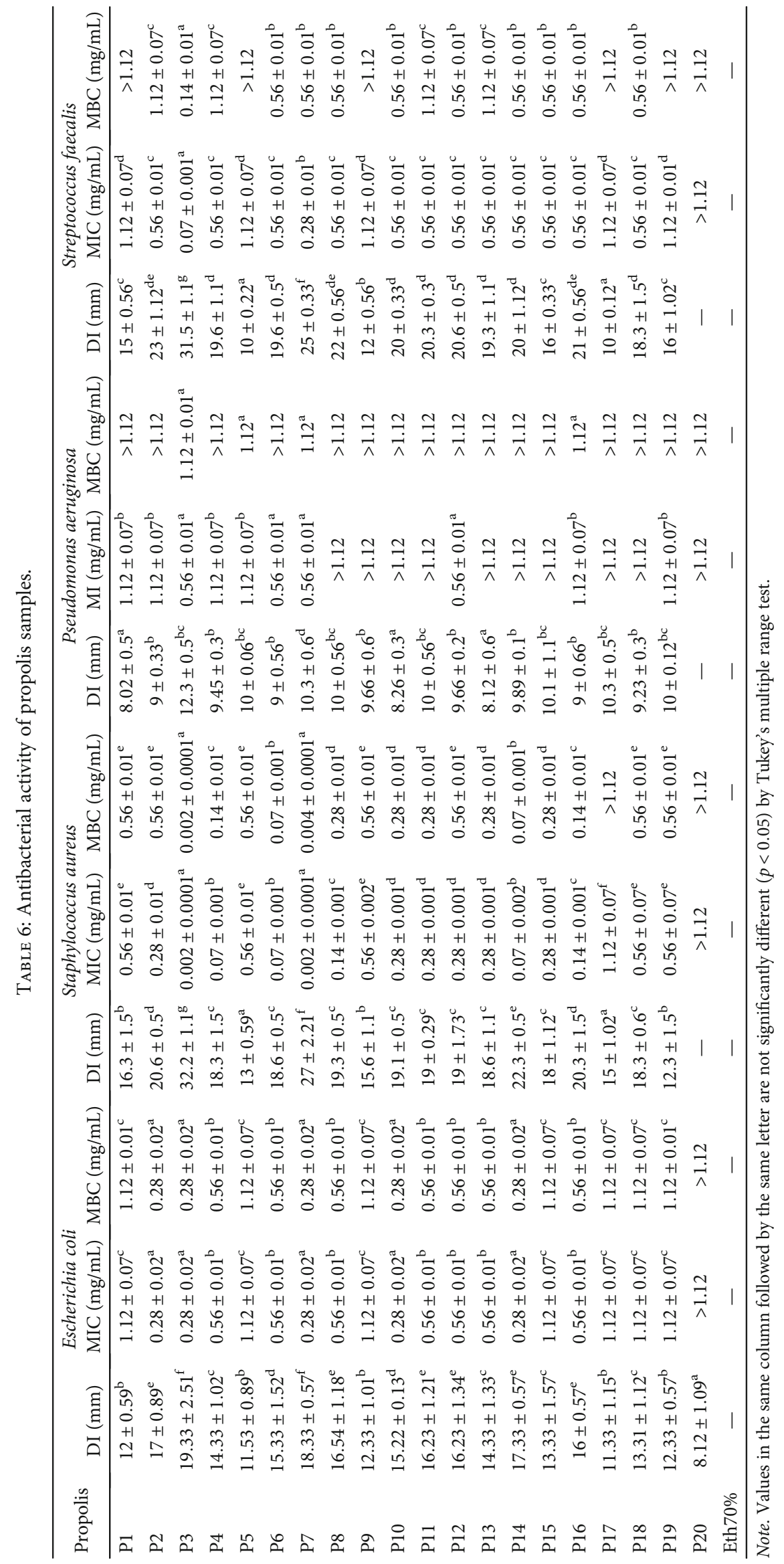




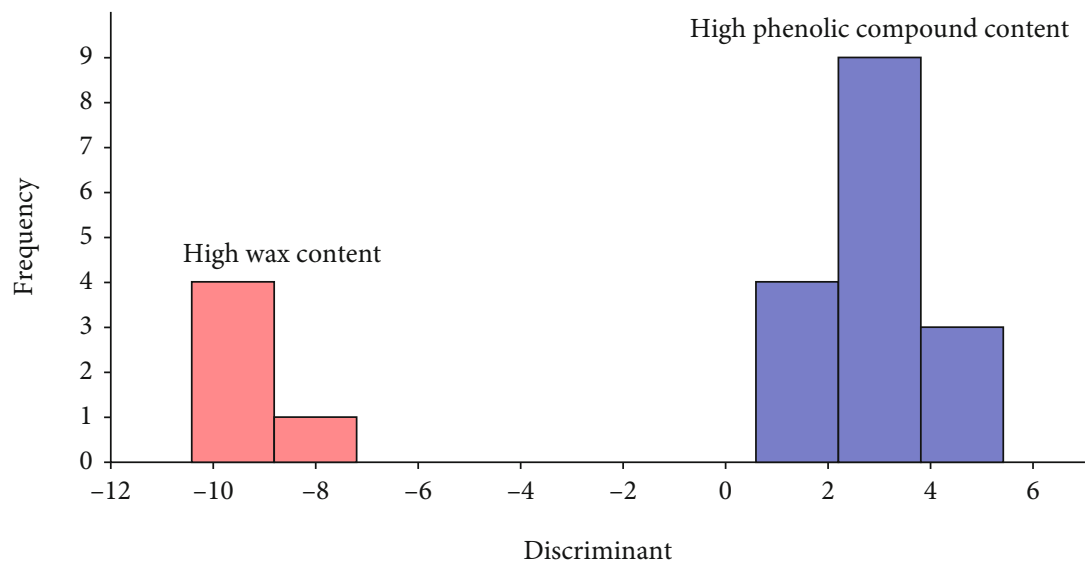

FIGURE 1: Histogram of canonical discriminant function considering the content of wax and phenolic compounds in propolis samples.

\section{Conclusion}

Overall, it can be concluded that Moroccan propolis with low wax content has high content of antioxidant compounds and high mineral contents and exhibits important biological activities. These findings could be related to the geographical and botanical origin of propolis, besides the good beekeeping practices and the choice of the right propolis traps to harvest clean and good quality propolis.

The present study will be helpful for the standardization of Moroccan propolis and could provide useful information for food and nutraceutical industries to choose high-quality propolis. Therefore, a thorough chemical characterization of a large number of samples is necessary to cover all aspects of propolis quality.

\section{Data Availability}

The data used to support the findings of this study are available from the corresponding author upon request.

\section{Conflicts of Interest}

The authors declare that they have no conflicts of interest.

\section{References}

[1] W. Gargouri, S. M. Osés, M. A. Fernández-Muiño, M. T. Sancho, and N. Kechaou, "Evaluation of bioactive compounds and biological activities of Tunisian propolis," $L W T$, vol. 111, pp. 328-336, 2019.

[2] J. K. S. Andrade, M. Denadai, C. S. de Oliveira, M. L. Nunes, and N. Narain, "Evaluation of bioactive compounds potential and antioxidant activity of brown, green and red propolis from Brazilian northeast region," Food Research International, vol. 101, pp. 129-138, 2017.

[3] L. de Alcântara Sica de Toledo, H. C. Rosseto, R. S. dos Santos et al., "Thermal magnetic field activated propolis release from liquid crystalline system based on magnetic nanoparticles," AAPS PharmSciTech, vol. 19, no. 7, pp. 3258-3271, 2018.

[4] R. Cauich-Kumul and M. R. S. Campos, "Chapter 12- bee propolis: properties, chemical composition, applications, and potential health effects," in Bioactive Compounds, M. R. S. Campos, Ed., pp. 227-243, Woodhead Publishing, 2019.

[5] B. Bueno-Silva, A. Marsola, M. Ikegaki, S. M. Alencar, and P. L. Rosalen, "The effect of seasons on Brazilian red propolis and its botanical source: chemical composition and antibacterial activity," Natural Product Research, vol. 31, no. 11, pp. 13181324, 2017.

[6] F. R. G. Silva, T. M. S. Matias, L. I. O. Souza et al., "Phytochemical screening and in vitro antibacterial, antifungal, antioxidant and antitumor activities of the red propolis Alagoas," Brazilian Journal of Biology, vol. 79, no. 3, pp. 452-459, 2019.

[7] I. AL-Ani, S. Zimmermann, J. Reichling, and M. Wink, “Antimicrobial activities of European propolis collected from various geographic origins alone and in combination with antibiotics," Medicines, vol. 5, no. 1, p. 2, 2018.

[8] R. Zeitoun, F. Najjar, B. Wehbi et al., "Chemical composition, antioxidant and anti-inflammatory activity evaluation of the Lebanese propolis extract," Current Pharmaceutical Biotechnology, vol. 20, no. 1, pp. 84-96, 2019.

[9] M. J. Kwon, H. M. Shin, H. Perumalsamy, X. Wang, and Y.J. Ahn, "Antiviral effects and possible mechanisms of action of constituents from Brazilian propolis and related compounds," Journal of Apicultural Research, vol. 59, no. 4, pp. 413-425, 2020.

[10] V. Tzankova, D. Aluani, Y. Yordanov et al., "Micellar propolis nanoformulation of high antioxidant and hepatoprotective activity," Revista Brasileira de Farmacognosia, vol. 29, no. 3, pp. 364-372, 2019.

[11] S. Touzani, W. Embaslat, H. Imtara et al., "In vitro evaluation of the potential use of propolis as a multitarget therapeutic product: physicochemical properties, chemical composition, and immunomodulatory, antibacterial, and anticancer properties," BioMed Research International, vol. 2019, Article ID 4836378, 11 pages, 2019.

[12] J. Daraghmeh and H. Imtara, "In vitro evaluation of Palestinian propolis as a natural product with antioxidant properties and antimicrobial activity against multidrug-resistant clinical isolates," Journal of Food Quality, vol. 2020, 10 pages, 2020.

[13] F. Galeotti, F. Maccari, A. Fachini, and N. Volpi, "Chemical composition and antioxidant activity of propolis prepared in different forms and in different solvents useful for finished products," Foods, vol. 7, no. 3, p. 41, 2018.

[14] M. M. Salem, T. Donia, R. Abu-Khudir, H. Ramadan, E. M. M. Ali, and T. M. Mohamed, "Propolis potentiates methotrexate 
anticancer mechanism and reduces its toxic effects," Nutrition and Cancer, vol. 72, no. 3, pp. 460-480, 2020.

[15] N. El Menyiy, N. Al Waili, M. Bakour, H. Al-Waili, and B. Lyoussi, "Protective effect of propolis in proteinuria, crystaluria, nephrotoxicity and hepatotoxicity induced by ethylene glycol ingestion," Archives of Medical Research, vol. 47, no. 7, pp. 526-534, 2016.

[16] S. El-Guendouz, S. Zizi, Y. Elamine, and B. Lyoussi, "Preliminary screening of the possible protective effect of Moroccan propolis against chromium-induced nephrotoxicity in animal model," Veterinary World, vol. 13, no. 7, pp. 1327-1333, 2020.

[17] N. el Menyiy, N. al-Waili, A. el Ghouizi, W. al-Waili, and B. Lyoussi, "Evaluation of antiproteinuric and hepato-renal protective activities of propolis in paracetamol toxicity in rats," Nutrition Research and Practice, vol. 12, no. 6, pp. 535-540, 2018.

[18] N. El Menyiy, N. Al-Wali, A. El Ghouizi, S. El-Guendouz, K. Salom, and B. Lyoussi, "Potential therapeutic effect of Moroccan propolis in hyperglycemia, dyslipidemia, and hepatorenal dysfunction in diabetic rats," Iranian journal of basic medical sciences, vol. 22, no. 11, pp. 1331-1339, 2019.

[19] H. Laaroussi, M. Bakour, D. Ousaaid et al., "Effect of antioxidant-rich propolis and bee pollen extracts against Dglucose induced type 2 diabetes in rats," Food Research International, vol. 138, p. 109802, 2020.

[20] S. el-Guendouz, S. Aazza, B. Lyoussi et al., "Moroccan propolis: a natural antioxidant, antibacterial, and antibiofilm against Staphylococcus aureus with no induction of resistance after continuous exposure," Evidence-Based Complementary and Alternative Medicine, vol. 2018, 19 pages, 2018.

[21] S. Touzani, N. al-Waili, N. el Menyiy et al., "Chemical analysis and antioxidant content of various propolis samples collected from different regions and their impact on antimicrobial activities," Asian Pacific Journal of Tropical Medicine, vol. 11, no. 7, p. 436, 2018.

[22] S. El-Guendouz, N. Al-Waili, S. Aazza et al., "Antioxidant and diuretic activity of co-administration of Capparis spinosa honey and propolis in comparison to furosemide," Asian Pacific Journal of Tropical Medicine, vol. 10, no. 10, pp. 974980, 2017.

[23] S. El-Guendouz, S. Aazza, B. Lyoussi, M. D. Antunes, M. L. Faleiro, and M. G. Miguel, "Anti-acetylcholinesterase, antidiabetic, anti-inflammatory, antityrosinase and antixanthine oxidase activities of Moroccan propolis," International Journal of Food Science \& Technology, vol. 51, no. 8, pp. 1762-1773, 2016.

[24] H. A. Mouse, M. Tilaoui, A. Jaafari et al., "Evaluation of the in vitro and in vivo anticancer properties of Moroccan propolis extracts," Revista Brasileira de Farmacognosia, vol. 22, no. 3, pp. 558-567, 2012.

[25] D. Devequi-Nunes, B. A. S. Machado, G. d. A. Barreto et al., "Chemical characterization and biological activity of six different extracts of propolis through conventional methods and supercritical extraction," PloS One, vol. 13, no. 12, article e0207676, 2018.

[26] J. H. d. O. Reis, G. d. A. Barreto, J. C. Cerqueira et al., "Evaluation of the antioxidant profile and cytotoxic activity of red propolis extracts from different regions of northeastern Brazil obtained by conventional and ultrasound-assisted extraction," PloS One, vol. 14, no. 7, article e0219063, 2019.

[27] L. G. Dias, A. P. Pereira, and L. M. Estevinho, "Comparative study of different Portuguese samples of propolis: pollinic, sensorial, physicochemical, microbiological characterization and antibacterial activity," Food and Chemical Toxicology, vol. 50, no. 12, pp. 4246-4253, 2012.

[28] R. El-Haskoury, W. Kriaa, B. Lyoussi, and M. Makni, “Ceratonia siliqua honeys from Morocco: physicochemical properties, mineral contents, and antioxidant activities," Journal of Food and Drug Analysis, vol. 26, no. 1, pp. 67-73, 2018.

[29] W. Horwitz, P. Chichilo, and H. Reynolds, "Official methods of analysis of the association of official analytical chemists," Journal of Pharmaceutical Sciences, vol. 60, no. 2, p. 334, 1971.

[30] G. Papotti, D. Bertelli, L. Bortolotti, and M. Plessi, “Chemical and functional characterization of Italian propolis obtained by different harvesting methods," Journal of Agricultural and Food Chemistry, vol. 60, no. 11, pp. 2852-2862, 2012.

[31] L. R. Silva, R. Videira, A. P. Monteiro, P. Valentão, and P. B. Andrade, "Honey from Luso region (Portugal): physicochemical characteristics and mineral contents," Microchemical Journal, vol. 93, no. 1, pp. 73-77, 2009.

[32] G. Zengin, T. Arkan, A. Aktumsek, G. O. Guler, and Y. S. Cakmak, "A study on antioxidant capacities and fatty acid compositions of two Daphne species from Turkey: new sources of antioxidants and essential fatty acids," Journal of Food Biochemistry, vol. 37, no. 6, pp. 646-653, 2013.

[33] M. d. G. Miguel, O. Doughmi, S. Aazza, D. Antunes, and B. Lyoussi, "Antioxidant, anti-inflammatory and acetylcholinesterase inhibitory activities of propolis from different regions of Morocco," Food Science and Biotechnology, vol. 23, no. 1, pp. 313-322, 2014.

[34] L. Moreira, L. G. Dias, J. A. Pereira, and L. Estevinho, “Antioxidant properties, total phenols and pollen analysis of propolis samples from Portugal," Food and Chemical Toxicology, vol. 46, no. 11, pp. 3482-3485, 2008.

[35] A. W. Bauer, W. M. M. Kirby, J. C. Sherris, and M. Turck, "Antibiotic susceptibility testing by a standardized single disk method," American Journal of Clinical Pathology, vol. 45, no. 4_ts, pp. 493-496, 1966.

[36] National Committee for Clinical Laboratory Standards, Document M100-S11, Performance Standards for Antimicrobial Susceptibility Testing, National Committee for Clinical Laboratory Standards, Wayne PA USA, 2003.

[37] D. Dimitrijević, "Antioxidant and antimicrobial activity of different extracts from leaves and roots of Jovibarba heuffelii (Schott.) A. Löve and D. Löve," Journal of Medicinal Plants Research, vol. 6, no. 33, 2012.

[38] P. Berche, J. L. Gaillard, and M. Simonet, "Les bactéries des infections humaines, Éd. Sciences," Flammarion Médecine, 1991.

[39] S. Katekhaye, H. Fearnley, J. Fearnley, and A. Paradkar, "Gaps in propolis research: challenges posed to commercialization and the need for an holistic approach," Journal of Apicultural Research, vol. 58, no. 4, pp. 604-616, 2019.

[40] Y. L. Chew, E. W. Ling Chan, P. L. Tan, Y. Y. Lim, J. Stanslas, and J. K. Goh, "Assessment of phytochemical content, polyphenolic composition, antioxidant and antibacterial activities of Leguminosae medicinal plants in Peninsular Malaysia," BMC Complementary and Alternative Medicine, vol. 11, no. 1, p. 12, 2011.

[41] Y. K. Park, S. M. Alencar, and C. L. Aguiar, "Botanical origin and chemical composition of Brazilian propolis," Journal of Agricultural and Food Chemistry, vol. 50, no. 9, pp. 25022506, 2002. 
[42] Brazil, Ministry of Health, National Health Surveillance Agency (ANVISA), Normative Instruction N 3, of January 19, 2001: Technical Regulations of Identify and Quality of Bee Venom, Royal Bee, Jelly Wax, Lyophilized Royal Jelly, Bee Pollen, Propolis and Propolis extract, Ministry of Health. National Health Surveillance Agency (ANVISA), Brasilia, Brazil, 2001.

[43] J. S. Bonvehí and F. J. O. Bermejo, "Element content of propolis collected from different areas of south Spain," Environmental Monitoring and Assessment, vol. 185, no. 7, pp. 6035-6047, 2013.

[44] J. P. B. Sousa, N. A. J. C. Furtado, R. Jorge, A. E. E. Soares, and J. K. Bastos, "Perfis físico-químico e cromatográfico de amostras de própolis produzidas nas microrregiões de Franca (SP) e Passos (MG), Brasil," Revista Brasileira de Farmacognosia, vol. 17, no. 1, pp. 85-93, 2007.

[45] A. I. Tikhonov, D. P. Salo, O. R. Pryakhin, and V. I. Gritsenko, "Standardization of propolis," Pharmaceutical Chemistry Journal, vol. 11, no. 12, pp. 1694-1699, 1977.

[46] A. Sales, A. Alvarez, M. R. Areal et al., "The effect of different propolis harvest methods on its lead contents determined by ET AAS and UV-visS," Journal of Hazardous Materials, vol. 137, no. 3, pp. 1352-1356, 2006.

[47] S. Gong, L. Luo, W. Gong, Y. Gao, and M. Xie, "Multivariate analyses of element concentrations revealed the groupings of propolis from different regions in China," Food Chemistry, vol. 134, no. 1, pp. 583-588, 2012.

[48] T. Liben, M. Atlabachew, and A. Abebe, "Total phenolic, flavonoids and some selected metal content in honey and propolis samples from South Wolo zone, Amhara region, Ethiopia," Cogent Food \& Agriculture, vol. 4, no. 1, pp. 1-12, 2018.

[49] Z. Ahangari, M. Naseri, and F. Vatandoost, "Propolis: chemical composition and its applications in endodontics," Iranian Endodontic Journal, vol. 13, no. 3, pp. 285-292, 2018.

[50] C. Toreti, H. H. Sato, G. M. Pastore, and Y. K. Park, "Recent progress of propolis for its biological and chemical compositions and its botanical origin," Evidence-Based Complementary and Alternative Medicine, 2013, March 2020, http://www .hindawi.com/journals/ecam/2013/697390/.

[51] M. G. Miguel, S. Nunes, S. A. Dandlen, A. M. Cavaco, and M. D. Antunes, "Phenols, flavonoids and antioxidant activity of aqueous and methanolic extracts of propolis (Apis mellifera L.) from Algarve, south Portugal," Food Science and Technology, vol. 34, no. 1, pp. 16-23, 2014.

[52] S. Kumazawa, T. Ohta, K. Kaji, and T. Nakayama, "Antioxidant and antiangiogenic activities of propolis," Yakugaku Zasshi-Journal of the Pharmaceutical Society of Japan, vol. 127, pp. 16-18, 2007.

[53] Y. M. Boufadi, J. Soubhye, A. Riazi et al., "Characterization and antioxidant properties of six Algerian propolis extracts: ethyl acetate extracts inhibit myeloperoxidase activity," International journal of molecular sciences, vol. 15, no. 2, pp. 23272345, 2014.

[54] W. Gao, L. Pu, J. Wei et al., "Serum antioxidant parameters are significantly increased in patients with type 2 diabetes mellitus after consumption of Chinese propolis: a randomized controlled trial based on fasting serum glucose level," Diabetes Therapy, vol. 9, no. 1, pp. 101-111, 2018.

[55] V. S. Bankova, S. L. de Castro, and M. C. Marcucci, "Propolis: recent advances in chemistry and plant origin," Apidologie, vol. 31, no. 1, pp. 3-15, 2000.
[56] S. Kumazawa, T. Hamasaka, and T. Nakayama, "Antioxidant activity of propolis of various geographic origins," Food Chemistry, vol. 84, no. 3, pp. 329-339, 2004.

[57] J. M. Sforcin and V. Bankova, "Propolis: is there a potential for the development of new drugs?," Journal of Ethnopharmacology, vol. 133, no. 2, pp. 253-260, 2011.

[58] I. Przybyłek and T. M. Karpiński, "Antibacterial properties of propolis,” Molecules, vol. 24, no. 11, p. 2047, 2019.

[59] J. M. Sforcin, A. Fernandes, C. A. M. Lopes, V. Bankova, and S. R. C. Funari, "Seasonal effect on Brazilian propolis antibacterial activity," Journal of Ethnopharmacology, vol. 73, no. 1-2, pp. 243-249, 2000.

[60] F. A. Santos, E. M. A. F. Bastos, M. Uzeda, M. A. R. Carvalho, L. M. Farias, and E. S. A. Moreira, "Antibacterial activity of propolis produced in Brazil against Actinobacillus actinomycetemcomitans, Fusobacterium spp. and bacteria from the Bacteroides fragilis group isolated from human and marmoset hosts," Anaerobe, vol. 5, no. 3-4, pp. 479-481, 1999.

[61] S. Sharaf, A. Higazy, and A. Hebeish, "Propolis induced antibacterial activity and other technical properties of cotton textiles," International Journal of Biological Macromolecules, vol. 59, pp. 408-416, 2013.

[62] H. Tsuchiya and M. Iinuma, "Reduction of membrane fluidity by antibacterial sophoraflavanone G isolated from Sophora exigua," Phytomedicine, vol. 7, no. 2, pp. 161-165, 2000.

[63] O. K. Mirzoeva, R. N. Grishanin, and P. C. Calder, “Antimicrobial action of propolis and some of its components: the effects on growth, membrane potential and motility of bacteria," Microbiological Research, vol. 152, no. 3, pp. 239-246, 1997.

[64] M. Claudel, J. V. Schwarte, and K. M. Fromm, "New antimicrobial strategies based on metal complexes," Chemistry, vol. 2, no. 4, pp. 849-899, 2020.

[65] M. S. Hossain, C. M. Zakaria, and M. Kudrat-E-Zahan, "Metal complexes as potential antimicrobial agent: a review," American Journal of Heterocyclic Chemistry, vol. 4, no. 1, p. 1, 2018.

[66] J. S. T. Jeloková, "Inhibition of bacterial DNA-dependent RNA polymerases and restriction endonuclease by UV-absorbing components from propolis," Pharmazie, vol. 41, no. 2, pp. 131-132, 1986.

[67] Y. K. Park, M. H. Koo, J. A. S. Abreu, M. Ikegaki, J. A. Cury, and P. L. Rosalen, "Antimicrobial activity of propolis on oral microorganisms," Current Microbiology, vol. 36, no. 1, pp. 24-28, 1998.

[68] N. Takaisi-Kikuni and H. Schilcher, "Electron microscopic and microcalorimetric investigations of the possible mechanism of the antibacterial action of a defined propolis provenance," Planta Medica, vol. 60, no. 3, pp. 222-227, 1994.

[69] P. G. Pietta, C. Gardana, and A. M. Pietta, "Analytical methods for quality control of propolis," Fitoterapia, vol. 73, Supplement 1, pp. S7-20, 2002. 